\title{
Cardiac resynchronization therapy; evaluation by advanced imaging techniques
}

\author{
E. E. van der Wall • M. J. Schalij · J. J. Bax
}

Received: 7 December 2009/Accepted: 14 December 2009/Published online: 29 December 2009

(C) The Author(s) 2009. This article is published with open access at Springerlink.com

Cardiac resynchronisation therapy (CRT) is an effective treatment for patients with advanced heart failure (HF), New York Heart Association class (NYHA) III or IV, a reduced left ventricular ejection fraction ( $\mathrm{LVEF}<35 \%$ ), and wide QRS complexes $(>120 \mathrm{~ms})$ [1, 2]. The beneficial effects include improvement in HF symptoms, exercise capacity, and LV function, as well as less HF hospitalizations and lower mortality rates. Despite these impressive results around $30 \%$ of patients show no benefit after CRT, being the so-called 'non-responders' [3-5]. The presence of LV dyssynchrony prior to implantation and its subsequent reduction after implantation are proposed the key mechanism for response to CRT. Initially, QRS duration was used as a marker of LV dyssynchrony. Recently, various studies have demonstrated that patients with extensive baseline LV dyssynchrony have a high likelihood of responding after CRT implantation, whereas patients without baseline LV dyssynchrony fail to benefit [6-8].

A variety of techniques has been proposed to quantify LV dyssynchrony in HF patients, ranging from simple M-mode echocardiography to more

Editorial comment on the article of Pavlopoulos and Nihoyannopoulos (doi: 10.1007/s10554-009-9523-5).

E. E. van der Wall $(\bowtie) \cdot$ M. J. Schalij · J. J. Bax Department of Cardiology, Leiden University Medical Center, P.O. Box 9600, Leiden, The Netherlands e-mail: e.e.van_der_wall@lumc.nl sophisticated techniques such as tissue Doppler imaging (TDI), real time three-dimensional echocardiography (RT3DE), and strain imaging techniques including speckle tracking [9]. Recent research using advanced echocardiographic modalities have provided new insight on the proper patient selection, lead implantation, optimization and reasons for nonresponse [10,11].

In the current issue of the International Journal of Cardiovascular Imaging, Pavlopoulos and Nihoyannopoulos [12] discuss the recent advances of echocardiography in the evaluation of patients eligible for CRT. The authors nicely describe the various parameters that can be used for optimal patient selection and for evaluation of the response to therapy. Advanced echocardiographic modalities do provide new insights on proper patient selection, lead implantation, optimization and reasons for non-response. Several echocardiographic parameters can be used in order to define the acute or long-term CRT responses. These parameters are changes in LVEF $\geq 15 \%$, reverse LV remodeling ( $\mathrm{LV}$ end-systolic dimensions/volumes $\geq 15 \%$ ); degree of mitral regurgitation, $\mathrm{dp} / \mathrm{dt}$, and cardiac output. Interestingly, the authors point out that overall assessment of echocardiographic parameters appears to contribute significantly to the outcome of CRT beyond electrical or mechanical dyssynchrony.

In addition to the described echocardiographic parameters, several non-echocardiographic imaging techniques such as magnetic resonance imaging (MRI), nuclear imaging, and computed tomography 
(CT) have also been advocated to evaluate patients with LV dyssynchrony. The use of MRI has been proven for patients with a variety of cardiac diseases [13-20] and is rapidly expanding for selecting patients for CRT [21-24]. Cardiac MRI does not only provide information on size, shape and function of the LV (which is of interest in patients with a suboptimal acoustic window), but also on LV dyssynchrony. In particular the identification of scar tissue is of paramount interest in patients eligible for CRT in selecting the optimal positioning of the pacing lead. Westenberg et al. [23] compared LV dyssynchrony assessed by TDI with LV dyssynchrony assessed by velocity-encoded MRI in $20 \mathrm{HF}$ patients and found an excellent agreement between both modalities ( $r=0.97, P<0.01)$. With contrastenhancement MRI accurate visualization of scar tissue was possible. Bleeker et al. [24] applied this technique in 40 patients with ischemic HF and investigated the relationship between response to CRT and the presence of scar tissue in the posterolateral wall, being the preferred region for the LV pacing lead. After 6 months of CRT, 21 of the 26 $(81 \%)$ patients without transmural scar tissue in the posterolateral region responded to CRT compared with only two of the $14(14 \%)$ patients with transmural scar tissue in the posterolateral area $(P<0.01)$. Moreover, patients with transmural posterolateral scarring exhibited no significant reduction in LV dyssynchrony the day after CRT implantation, suggesting absence of LV resynchronization, thereby explaining the lack of response.

Similar to MRI, nuclear imaging is well suited for the assessment of viability, scar tissue [25-31], and LV dyssynchrony [32-35]. Only a few studies used radionuclide angiography with phase image analysis for the assessment of LV and interventricular dyssynchrony in CRT candidates [35, 36]. However, these studies demonstrate greatest benefit of CRT in patients with LV rather than interventricular dyssynchrony. This finding is in contrast with larger TDI studies, and further studies including comparisons with TDI are therefore required. Recent studies showed that gated SPECT imaging can be used for the assessment of LV dyssynchrony [37, 38]. Henneman et al. [37] analyzed four quantitative indices of phase analysis in $75 \mathrm{HF}$ patients and compared them with conventional TDI. The variables histogram bandwidth and phase standard deviation showed a good correlation with TDI. In addition, cut-off values of $135^{\circ}$ for histogram bandwidth and $43^{\circ}$ for phase standard deviation were proposed to predict an improvement in NYHA class after CRT. In addition, nuclear imaging is well suited for assessment of viability and scar tissue. Sciagra et al. [38] were the first to demonstrate that patients with severe resting defects at 99mTc-sestamibi SPECT imaging at baseline showed lack of response after CRT.

Computed tomography (CT) techniques can not yet be used to determine LV dyssynchrony itself, but CT does allow noninvasive visualization of the coronary anatomy and the coronary venous system [39-52]. Van de Veire et al. [53] investigated the cardiac venous anatomy in 34 patients with a previous myocardial infarction, 38 patients with significant coronary artery disease and 28 control patients using a 64-slice MSCT. The coronary sinus, anterior interventricular vein, and posterior interventricular vein could be visualized in nearly all these patients. However, in patients with a history of myocardial infarction, the left marginal vein was detected significantly less often (27\%). At present, MSCT is not routinely used prior to CRT implantation, mainly because of the radiation dose and lack of information on LV dyssynchrony and site of latest activation [54]. However, these findings suggest that patients with previous infarction may have less suitable venous anatomy for LV lead placement, and surgical (epicardial) LV lead positioning may be considered.

To summarize, several noninvasive imaging modalities have been proposed for the quantification of LV dyssynchrony but there is currently no agreement on which technique best predicts response to CRT. For now, most experience is gained with echocardiographic TDI and it remains the technique of choice, as also mentioned by Pavlopoulos and Nihoyannopoulos [12]. Major consensus is 'the more LV dyssynchrony prior to implantation, the higher the likelihood of significant LV reverse remodeling during follow-up'. At present, substantial evidence is growing for non-echocardiographic imaging methods to assess LV dyssynchrony such as MRI, nuclear imaging and CT. These techniques may provide valuable additional information that is potentially important for the selection of CRT candidates. 
Open Access This article is distributed under the terms of the Creative Commons Attribution Noncommercial License which permits any noncommercial use, distribution, and reproduction in any medium, provided the original author(s) and source are credited.

\section{References}

1. Bax JJ, Bleeker GB, Marwick TH et al (2004) Left ventricular dyssynchrony predicts response and prognosis after cardiac resynchronization therapy. J Am Coll Cardiol 44: $1834-1840$

2. Bleeker GB, Schalij MJ, Boersma E et al (2007) Relative merits of M-mode echocardiography and tissue Doppler imaging for prediction of response to cardiac resynchronization therapy in patients with heart failure secondary to ischemic or idiopathic dilated cardiomyopathy. Am J Cardiol 99:68-74

3. Ypenburg C, van der Wall EE, Schalij MJ, Bax JJ (2008) Imaging in cardiac resynchronisation therapy. Neth Heart $\mathrm{J}$ 16:S36-S40

4. Buck S, Maass AH, van Veldhuisen DJ, Van Gelder IC (2009) Cardiac resynchronisation therapy and the role of optimal device utilisation. Neth Heart J 17:354-357

5. van Hemel NM, Scheffer M (2009) Cardiac resynchronisation therapy in daily practice and loss of confidence in predictive techniques to response. Neth Heart J 17:4-5

6. Ypenburg C, Westenberg JJ, Bleeker GB et al (2008) Noninvasive imaging in cardiac resynchronization therapy-part 1: selection of patients. Pacing Clin Electrophysiol 31:1475-1499

7. Bleeker GB, Yu CM, Nihoyannopoulos P et al (2007) Optimal use of echocardiography in cardiac resynchronisation therapy. Heart 93:1339-1350

8. Jansen AH, van Gelder BM (2008) Visual LV motion and invasive $\mathrm{LVdP} / \mathrm{dtmax}$ for selection and optimisation of cardiac resynchronisation therapy. Neth Heart J 16(Suppl 1):S32-S35

9. Tops LF, Suffoletto MS, Bleeker GB et al (2007) Speckletracking radial strain reveals left ventricular dyssynchrony in patients with permanent right ventricular pacing. J Am Coll Cardiol 50:1180-1188

10. Sá MI, de Roos A, Westenberg JJ, Kroft LJ (2008) Imaging techniques in cardiac resynchronization therapy. Int $\mathbf{J}$ Cardiovasc Imaging 24:89-105

11. Bertini M, Delgado V, Bax JJ, Van de Veire NR (2009) Why, how and when do we need to optimize the setting of cardiac resynchronization therapy? Europace 11(Suppl 5): v46-57

12. Pavlopoulos H, Nihoyannopoulos P (2009) Recent advances in cardiac resynchronization therapy: echocardiographic modalities, patient selection, optimization, non-respondersall you need to know for more efficient CRT. Int J Cardiovasc Imaging. doi:10.1007/s10554-009-9523-5

13. van der Wall EE, van Dijkman PR, de Roos A et al (1990) Diagnostic significance of gadolinium-DTPA (diethylenetriamine penta-acetic acid) enhanced magnetic resonance imaging in thrombolytic treatment for acute myocardial infarction: its potential in assessing reperfusion. Br Heart $\mathrm{J}$ 63:12-17

14. van Dijkman PR, van der Wall EE, de Roos A et al (1991) Acute, subacute, and chronic myocardial infarction: quantitative analysis of gadolinium-enhanced MR images. Radiology 180:147-151

15. de Roos A, Matheijssen NA, Doornbos J, van Dijkman PR, van Voorthuisen AE, van der Wall EE (1990) Myocardial infarct size after reperfusion therapy: assessment with Gd-DTPA-enhanced MR imaging. Radiology 176:517-521

16. Pluim BM, Lamb HJ, Kayser HW et al (1998) Functional and metabolic evaluation of the athlete's heart by magnetic resonance imaging and dobutamine stress magnetic resonance spectroscopy. Circulation 97:666-672

17. Vliegen HW, Doornbos J, de Roos A, Jukema JW, Bekedam MA, van der Wall EE (1997) Value of fast gradient echo magnetic resonance angiography as an adjunct to coronary arteriography in detecting and confirming the course of clinically significant coronary artery anomalies. Am J Cardiol 79:773-776

18. Hoogendoorn LI, Pattynama PM, Buis B, van der Geest RJ, van der Wall EE, de Roos A (1995) Noninvasive evaluation of aortocoronary bypass grafts with magnetic resonance flow mapping. Am J Cardiol 75:845-848

19. Holman ER, Buller VG, de Roos A et al (1997) Detection and quantification of dysfunctional myocardium by magnetic resonance imaging. A new three-dimensional method for quantitative wall-thickening analysis. Circulation 95: 924-931

20. Schuijf JD, Bax JJ, van der Wall EE (2007) Anatomical and functional imaging techniques: basically similar or fundamentally different? Neth Heart J 15:43-44

21. Ypenburg C, Roes SD, Bleeker GB et al (2007) Effect of total scar burden on contrast-enhanced magnetic resonance imaging on response to cardiac resynchronization therapy. Am J Cardiol 99:657-660

22. Rüssel IK, van Dijk J, Kleijn SA et al (2009) Relation between three-dimensional echocardiography derived left ventricular volume and MRI derived circumferential strain in patients eligible for cardiac resynchronization therapy. Int J Cardiovasc Imaging 25:1-11

23. Westenberg JJ, Lamb HJ, van der Geest RJ et al (2006) Assessment of left ventricular dyssynchrony in patients with conduction delay and idiopathic dilated cardiomyopathy: head-to-head comparison between tissue doppler imaging and velocity-encoded magnetic resonance imaging. J Am Coll Cardiol 47:2042-2048

24. Bleeker GB, Kaandorp TA, Lamb HJ et al (2006) Effect of posterolateral scar tissue on clinical and echocardiographic improvement after cardiac resynchronization therapy. Circulation 113:969-976

25. van der Wall EE, Heidendal GA, den Hollander W, Westera G, Roos JP (1980) I-123 labeled hexadecenoic acid in comparison with thallium-201 for myocardial imaging in coronary heart disease. A preliminary study. Eur J Nucl Med 5:401-405

26. Bax JJ, Lamb H, Dibbets P et al (2000) Comparison of gated single-photon emission computed tomography with magnetic resonance imaging for evaluation of left ventricular function in ischemic cardiomyopathy. Am J Cardiol 86:1299-1305 
27. Bavelaar-Croon CD, Pauwels EK, van der Wall EE (2001) Gated single-photon emission computed tomographic myocardial imaging: a new tool in clinical cardiology. Am Heart J 141:383-390

28. Chamuleau SA, van Eck-Smit BL, Meuwissen $M$ et al (2007) Long-term prognostic value of CFVR and FFR versus perfusion scintigraphy in patients with multivessel disease. Neth Heart J 15:369-374

29. Bavelaar-Croon CD, Kayser HW, van der Wall EE et al (2000) Left ventricular function: correlation of quantitative gated SPECT and MR imaging over a wide range of values. Radiology 217:572-575

30. van Rugge FP, Boreel JJ, van der Wall EE et al (1990) Cardiac first-pass and myocardial perfusion in normal subjects assessed by sub-second Gd-DTPA enhanced MR imaging. J Comput Assist Tomogr 15:959-965

31. van der Wall EE, den Hollander W, Heidendal GA, Westera G, Majid PA, Roos JP (1981) Dynamic myocardial scintigraphy with 123I-labeled free fatty acids in patients with myocardial infarction. Eur J Nucl Med 6:383-389

32. Ypenburg C, Schalij MJ, Bleeker GB et al (2006) Extent of viability to predict response to cardiac resynchronization therapy in ischemic heart failure patients. J Nucl Med 47:1565-1570

33. Henneman MM, van der Wall EE, Ypenburg C et al (2007) Nuclear imaging in cardiac resynchronization therapy. J Nucl Med 48:2001-2010

34. Boogers MM, Chen J, Bax JJ (2008) Myocardial perfusion single photon emission computed tomography for the assessment of mechanical dyssynchrony. Curr Opin Cardiol 23:431-439

35. Marcassa C, Campini R, Verna E, Ceriani L, Giannuzzi P (2007) Assessment of cardiac asynchrony by radionuclide phase analysis: correlation with ventricular function in patients with narrow or prolonged QRS interval. Eur J Heart Fail 9:484-490

36. Wassenaar R, O'Connor D, Dej B, Ruddy TD, Birnie D (2009) Optimization and validation of radionuclide angiography phase analysis parameters for quantification of mechanical dyssynchrony. J Nucl Cardiol 16:895-903

37. Henneman MM, Chen J, Dibbets-Schneider P et al (2007) Dyssynchrony as assessed with phase analysis on gated myocardial perfusion Spect predict response to CRT? J Nucl Med 48:1104-1111

38. Sciagra R, Giaccardi M, Porciani MC et al (2004) Myocardial perfusion imaging using gated SPECT in heart failure patients undergoing cardiac resynchronization therapy. J Nucl Med 45:164-168

39. de Leeuw JG, Wardeh A, Sramek A, van der Wall EE (2007) Pseudo-aortic dissection after primary PCI. Neth Heart J 15:265-266

40. Braun S, van der Wall EE, Emanuelsson S, Kobrin I (1996) Effects of a new calcium antagonist, mibefradil (Ro 405967), on silent ischemia in patients with stable chronic angina pectoris: a multicenter placebo-controlled study. The mibefradil international study group. J Am Coll Cardiol 27:317-322
41. Portegies MC, Schmitt R, Kraaij CJ et al (1991) Lack of negative inotropic effects of the new calcium antagonist Ro 40-5967 in patients with stable angina pectoris. J Cardiovasc Pharmacol 18:746-751

42. ten Kate GJ, Wuestink AC, de Feyter PJ (2008) Coronary artery anomalies detected by MSCT-angiography in the adult. Neth Heart J 16:369-375

43. Bakx AL, van der Wall EE, Braun S, Emanuelsson H, Bruschke AV, Kobrin I (1995) Effects of the new calcium antagonist mibefradil (Ro 40-5967) on exercise duration in patients with chronic stable angina pectoris: a multicenter, placebo-controlled study. Ro 40-5967 International Study Group. Am Heart J 130:748-757

44. Schuijf JD, Pundziute G, Jukema JW et al (2006) Diagnostic accuracy of 64-slice multislice computed tomography in the noninvasive evaluation of significant coronary artery disease. Am J Cardiol 98:145-148

45. Groen JM, Greuter MJ, Vliegenthart R et al (2008) Calcium scoring using 64-slice MDCT, dual source CT and EBT: a comparative phantom study. Int $\mathrm{J}$ Cardiovasc Imaging 24:547-556

46. Schuijf JD, Jukema JW, van der Wall EE, Bax JJ (2007) Multi-slice computed tomography in the evaluation of patients with acute chest pain. Acute Card Care 9:214-221

47. Tops LF, Bax JJ, Zeppenfeld K et al (2005) Fusion of multislice computed tomography imaging with threedimensional electroanatomic mapping to guide radiofrequency catheter ablation procedures. Heart Rhythm 2:1076-1081

48. Henneman MM, Schuijf JD, Pundziute G et al (2008) Noninvasive evaluation with multislice computed tomography in suspected acute coronary syndrome: plaque morphology on multislice computed tomography versus coronary calcium score. J Am Coll Cardiol 52:216-222

49. de Nooijer R, Verkleij CJ, von der Thüsen JH et al (2006) Lesional overexpression of matrix metalloproteinase-9 promotes intraplaque hemorrhage in advanced lesions but not at earlier stages of atherogenesis. Arterioscler Thromb Vasc Biol 26:340-346

50. van der Laarse A, Kerkhof PL, Vermeer F et al (1988) Relation between infarct size and left ventricular performance assessed in patients with first acute myocardial infarction randomized to intracoronary thrombolytic therapy or to conventional treatment. Am J Cardiol 61:1-7

51. van der Hoeven BL, Pires NM, Warda HM et al (2005) Drug-eluting stents: results, promises and problems. Int $\mathbf{J}$ Cardiol 99:9-17

52. Jongbloed MR, Lamb HJ, Bax JJ et al (2005) Noninvasive visualization of the cardiac venous system using multislice computed tomography. J Am Coll Cardiol 45:749-753

53. Van de Veire NR, Schuijf JD et al (2006) Non-invasive visualization of the cardiac venous system in coronary artery disease patients using 64-slice computed tomography. J Am Coll Cardiol 48:1832-1838

54. Van de Veire NR, Delgado V, Schuijf JD, van der Wall EE, Schalij MJ, Bax JJ (2009) The role of non-invasive imaging in patient selection. Europace 11(Supp15):v32-39 